\title{
RECENT PROGRESS TOWARDS AGREEMENT ON RULES TO PREVENT A CONFLICT OF LAWS.
}

DUBLIC International Law overshadows what we are accustomed, rightly or wrongly, to term Private International Law. It overshadows it both in dignity of character and in fixedness of character. No one now doubts that there is a public international law of binding force, so far as any law can be declared obligatory for which no sovereign has supplied or can supply a sanction. That it exists and is a part of the common law of England has been the doctrine of Anglo-American courts since the middle of the last century. That it exists and has a binding force is assumed in the Constitution of the United States, in its provision that Congress may define and punish offenses against the Law of Nations. It defines, but does not create them. ${ }^{1}$

Private international law stands on very different ground. It is only an expression of the opinion of particular courts or jurists as to what law should be applied to the determination of a question involving private rights of foreigners or private rights claimed by virtue of some foreign transaction. It is a doctrine of preferences between different laws of different sovereigns. The old name of Conflict of Laws is still the more scientific one, and Germany and Italy not unreasonably adhere to it. Private international law is something to which the world is working up. It is, in strictness, a term of the future.

A Dutch jurist, Dr. Jitta of Amsterdam, in I890 published a volume entitled " Méthode du Droit International Prive," in which he asserts that the growth of civilization has brought us to a point where we can recognize rights of man as a citizen of the world which are superior to any rights that a particular State can give to its particular citizens. But there are few subjects as to which humanitarian and sentimental considerations can fairly be expected to lead to international legislation. There is a field for the Red Cross. There was a legitimate standing ground for the Hague

1 United States v. Arjona, 120 U. S. 479, 488. 
Convention of 1899 as to the conduct of war. When, however, we come to such subjects as the weight to be given to foreign judgments, or the rights of a foreign guardian, we get little aid from the impulses of humane feeling or the modern sense of the brotherhood of man. It is not by a priori comprehensive schemes of world-law that provision is to be made for the ordinary cases of a conflict of laws. It must come, like every other thing of permanence and value, by a slow course of progress from small beginnings.

In 1889 a South American Congress of Private International Law sat at Montevideo to concert some general continental scheme of regulation. Seven nations were represented. Eight conventions were framed, comprehending almost a code upon the subject, which have since been made the basis of treaties between several of these powers. ${ }^{1}$ All European nations were invited to become parties to these conventions, and there is reason to think that Spain gave the matter some consideration before the war which drove her out of Cuba and so largely destroyed her interest in American affairs. In 1900 she brought it before an informal gathering of the States of Latin America, which she summoned at Madrid. Fifteen of them were represented, and the results reached at Montevideo were favorably considered.

The second Pan-American Congress, which met at Mexico in I90I-2, set out to accomplish a still more ambitious task. This was the preparation of a code both of Public and of Private International Law, to be drawn up as soon as may be by a commission of five American and two European jurists.

Meanwhile Europe had gone to work in a more modest and quiet way. There was no attempt to call a Pan-European Congress. There was no desire that all Europe should participate in it.

In 1893 the Netherlands issued invitations to such European States as she judged best, to send delegates to a Conference at the Hague to consider the adoption of identical laws or of an international convention on certain subjects relating to personal status, private property, and the forms of legal documents. Thirteen nations sent delegates, and similar Conferences were held in I894 and 1900 , resulting in conventions for determining what law shall be applicable in case of conflicting claims as to matters of marriage, divorce, and guardianship, and to successions and bankruptcies, and to regulate certain methods of judicial procedure

129 London Law Magazine and Review, 2. 26 
affecting foreigners. The conventions as to the celebration of marriage, adjudication of divorce and guardianship, were, by the summer of 1902, ratified by the executive departments of twelve of the powers. To that concerning successions ten acceded, but as Russia and Hungary refused their assent, the Netherlands has called another Conference to revise that and, as to some points, the others, which will assemble in May, 1904.

Ratification by the legislative departments is required in the case of a number of the powers concerned, and it may be presumed that this will be generally deferred until the Conference of I 904 has done its work.

The Netherlands has been criticised for not extending wider invitations to these Conferences. At the last meeting of the International Law Association, at Antwerp, in September, 1903, this feeling found some expression, and Dr. Meili, one of the Swiss delegates, in a work recently published, gives voice to the same opinion, in regard to the absence of England and the United States. ${ }^{1}$ There would seem, however, ample justification for omitting to invite them. The Netherlands wisely thought it best to move slowly, and in concert with those powers that might be expected to take the same view of many, if not most, of the questions to be presented. Only nations of eastern and central continental Europe therefore were asked to participate. There were points of difference enough between them, but they were neighbors, and most of them had a jurisprudence founded on the Roman law. The presence of representatives from insular England, and countries across the Atlantic, having a common law differing widely from the Roman, and a judicial system differing not less from that found generally on the continent, would have doubled the occasions of difference. It was natural to desire to get a continental agreement first, at least, before going beyond seas for new adherents. ${ }^{2}$

Take, for instance, the vexed question whether domicil or nationality should be the test of personal capacity. No advocate of nationality as the criterion would have welcomed the presence of Englishmen or Americans. Even the Latin-Americans at the Montevideo Congress had decided in favor of domicil. In the Hague conventions, however, that of nationality was agreed on.

1 Das internationale Civilprozessrecht auf Grund der Theorie, Gesetzgebung und Praxis, Zurich, 1904, p. 26.

2 See M. Asser's remarks on this subject on taking the Chair in the Conference of I894. Actes de la Deuxième Conférence de la Haye, etc. The Hague, 1894, p. 13. 
If the Hague conventions, as they may be revised and perfected this year, should go into full force in eastern and central Europe, it is probable that on certain points the United States would eventually be glad to express their concurrence in them, by some formal act of adherence, on the part of the treaty making power. There may be constitutional objections to such action in respect to some of the matters involved, owing to the peculiar relations of the States to the United States. But so far as the United States can speak, it would be obviously desirable that they should. The difficulties for instance now in the way of the marriage of Americans abroad are so great as to be almost prohibitory; and it is largely for want of a prescribed rule, applicable to those of every State. Congress has gone as far as it dared to venture by Revised Statutes $\S 4082$, which allows marriages before consular officers of those who would be authorized to marry if residing in the District of Columbia. The State Department, however, frowns upon such marriages, and with good reason. ${ }^{1}$ If the United States were now to recommend to the several States the enactment of identical laws in respect to foreign marriages of their citizens, conforming in whole or part to the conclusions of the Hague Conferences, it could hardly fail to be of advantage. Such a piece of advice might have been treated, fifty years ago, as a gratuitous interference with reserved rights, but it would shock few at the present day. The Civil War and the Fourteenth Amendment have brought the States and the United States into such intimate relations, and the objects to be attained are both so important and so far removed from party controversy, that any recommendation of this nature by Congress would at least receive the most respectful consideration.

The inconvenience resulting from a conflict of laws between our States on the subject of commercial paper has of late been largely avoided by the general adoption of the Negotiable Instruments' Act, framed by the Annual Conference of the States for Promoting Uniform Legislation. It is from the action of this body that the most is to be hoped for in the immediate future in smoothing the way to general agreement within the United States as to matters of private law. Identical statutes in different States avoid many questions incident to a choice between different statutes of different States. The existence of this American conference, as a permanent body, was one of the causes that encouraged the Netherlands to

${ }^{3} 3$ Wharton's Int. Law Dig. § 26 I. 
call the first Hague Conference. ${ }^{1}$ Its work ought to be forwarded by all who are interested in advancing the unity of American jurisprudençe.

It is understood that those in charge of the preparations for the Universal Congress of Jurists and Lawyers, to be held at St. Louis on September 28, 1904, are considering the advisability of bringing before that body for discussion some of the results of the Hague Conference of igoo. Such a step would serve at least one good purpose: it would give the American bench and bar a better knowledge of what Europe is now doing in the field of law reform. It might also lead to American legislation on the part of some of our States on the lines marked out at the Hague.

A somewhat similar Congress, that of Private International Law, which was an incident of the Paris Exposition of 1900 , initiated a movement that may prove of wide importance. This was the creation of a standing commission to endeavor to organize an international Institute, a leading object of which should be the collection and publication of statutes and judicial decisions of the different nations of the world.

The Brussels conferences of 1883 and 1886 initiated a movement in the same line, resulting in a convention between eight powers, which all of them ratified in 1889. As between the United States, Belgium, Brazil, Italy, Portugal, Servia, Spain, and Switzerland, this secured the prompt transmission by each government of copies of all its official publications, thereafter issued, to the bureau of international exchange in every other. A supplementary Convention between the same powers, excepting only Switzerland, also went into effect at the same time, under which copies of the parliamentary proceedings thereafter published by each are sent, also, direct to the legislative departments ${ }^{2}$ (aux chambres legislatives) in the rest. The absence of most of the great powers from the list of the adherents to these conventions. shows that they offer an imperfect measure of relief against a real evil, the ignorance of nine-tenths of the world as to the changes in the law which time is daily working.

This measure contemplates also the exchange of but a small part of what each country could furnish. It makes no provision for the publications made before 1889. So far as this country is

1 Actes de la Conférence de la Haye, chargée de règlémenter diverses matières de Droit International Privé. The Hague, 1893. pp. 625.

225 U. S. Statutes at Large, $1465-1471$. 
concerned, it makes none for those of the States. Nor does it look to the use of the material gathered for general information, in the shape of new publications.

The commission proposed by the Paris Congress of 1900 has a wider scope of duty and of possibility. Such a body could achieve a good deal, if it could form a connection with some public or quasipublic foundation, of a national character, like for instance in this country the Smithsonian Institution or the Carnegie Institute. It could decide what was worth publication and what was not, from a scientific point of view, unhampered by the requirements of official etiquette, and unembarrassed by a need of seeking the favor of administrative bureaus or legislative committees. If any great public library should be built up at some central point, under the patronage of a commission of this nature, it would mean a good deal; but of far more importance would be the use of this library as a source of selection by impartial judges for what of the modern law of every country is worth the knowledge of all countries.

YALE LAW School, Feb. 26, Ig04.

Simeon E. Baldwin. 